se encuentran, por esta razón es que nos permitirá ver como se están comercializando estos bellos lugares $y$ darle otra mirada, para que se reconozca el departamento como un destino ecoturístico, en sintonía con el planteamiento desarrollando en el marco del convenio del competitividad la Secretaria de Cultura y Turismo del departamento.

Este es un reto para el Grupo de investigación para la Animación Cultural "MUISUATA" ya que se consolidarán los nuevos marcos de referencia que aporten a la constitución de programas de desarrollo del destino ecoturístiço del departamento $y$ a su vez se constituya como el inicio la nueva visión del departamento para el mundo.

\title{
BIBLIOGRAFÍA.
}

- LASCURIAN, CEvallos, hector (1996). Los orígenes del ecoturismo.

- Conferencia Internacional de Biodiversidad y Turismo, (1997) Berlín, Alemania.

- República de Colombia. Ministerio de Desarrolło Económico, (1996). Ley General del turismo.

\section{LA ADMINISTRACIÓN: UN INTERESANTE CAMINO POR DESCUBRIR}

\section{Carmen Moraima Álvarez Rincón \\ Grupo Construyendo Comunidad Educativa}

Hoy se habla de administración al mencionar el programa, al nombrar una materia un hecho en una empresa por parte de sus dirigentes e incluso al referirnos al mismo gobierno pero, ¿qué tanto hemos indagado sobre su procedencia?, iacaso sabemos si el termino administración siempre fue de uso común?, co simplemente nos conformamos con saber to que en este momento nos significa o representa? Quizás, no le hemos dado la Importancia necesaria por esto es de interés retomar lo que se ha avanzado acerca de la administración.

Quien iba a pensar que los ejércitos griegos y romanos, la iglesia católica 
romana, entre otros, fueran ejemplo de organización, ni mucho menos que personajes como Maquiavelo hubiesen dejado un legado para la administración; pues bien, este personaje planteo principios que perfectamente se podían aplicar ahora:

"1. Una organización es mas estable si sus miembros tienen el derecho de manifestar sus diferencias y resolver sus conflictos dentro de ella.

2. Si bien una persona puede iniciar una organización "esta será duradera cuando se deja en manos de muchos y cuando muchos desean conservarla"

3. Un gerente que pretende cambiar una organización establecida debe conservar cuando menos la sombra de las costumbres antiguas. ${ }^{1}$

"El hombre primitivo cazaba animales. La casería exigía inteligencia, astucia y necesidad de aprender a casar en grupo. Es de suponer que debió existir alguna forma de racionalización del trabajo, de asignación de tareas bajo el mando de un jefe. Ese jefe primitivo es el símbolo lejano de nuestros empresarios, directivos y gerentes de hoy. ${ }^{2}$

Desde finales del siglo XIX se acostumbra a definir la administración en términos de cuatro funciones específicas: Organización, Dirección y Control de la siguiente manera:

Planificación: es un proceso donde se define y establece metas y el mejor método para alcanzarlas.

Organización: en este proceso se distribuye y ordena el trabajo es decir se entregan responsabilidades; pero cabe destacar que el diseño organizacional es supremamente importante puesto que los gerentes deben adaptar la estructura de la organización a sus metas y por supuesto a sus recursos.

Dirección: es un proceso donde el gerente o administrador se ve totalmente involucrado puesto que dirigir implica mandar motivar e influir a los empleados o miembros de la organización para que realicen una tarea. De esta manera los gerentes dirigen tratando de convencer a los demás para que junto a ellos logren los objetivos propuestos que surgen de la planificación y organización.

Control: en este proceso se asegura que las actividades contribuyan al cumplimiento de los objetivos así se evalúa y se hace seguimiento a lo que se este desarrollando para llegar a cumplir con lo planeado.

Cabe resaltar que estas funciones no son actividades independientes sino que son interrelacionadas, es decir, estas etapas interactúan para que así a través de ellas se cumpla con la visión, misión y objetivos de una organización.

${ }^{1}$ STONER, James. Administración. Prentice Hall, 1996, Pág. 32

${ }^{2}$ RAMIREZ, Carlos. Fundamentos de Administración. Ecoe Ediciones, 1999, Pág. 79 
La importancia de estas funciones y de un buen administrador radica en que toda organización sea industrial o sea para que preste algún tipo de servicio, indiscutiblemente necessita ser administrada adecuadamente para que pueda alcanzar sus objetivos.

La administración se desarrollo con una lentitud impresionante hasta la iniciación del siglo XX; hace 80 años las organizaciones eran pocas y pequeñas predominaban oficinas pequeñas, artesanos independientes, escuelas de menor tamaño, incluso en el ámbito de los profesionales podíamos ver médicos, abogados, etc. trabajaban por cuenta propia es por eso que la historia de las organizaciones y su administración ocurren hace relativamente poco tiempo. La evolución es más notoria ahora, pues en la mayoría de los países desarrollados hoy en día, obligación sociales como producción, servicio especializado de educación o salud etc. son confiadas o asignadas a organizaciones tales como industrias, universidades, hospitales, etc, es así como a partir del momento en que las organizaciones alcanzan cierto tamaño y comple jidad, su administración al igual que ellas empieza a presentar situaciones un tanto difíciles de superar para sus dirigente, de esta manera surge la necesidad de aplicar la teoría de la administración para que los dirigentes de las organizaciones tuviesen modelos y estrategias adecuadas para la solución de problemas empresariales.

A medida que se va avanzando en la evolución del mundo nos damos cuenta que para las organizaciones ya no solo sirve tener una buena contabilidad, ni gerencias eficaces en cuanto a resultados técnicos, ri mucho menos pensar en tener la mejor maquinaria para asegurar el éxito de su empresa ahora se tiene que enfatizar también en que no solo basta con trabajar y trabajar sino que las personas y su entorno son de vital importancia para el buen funcionamiento de una organización ya sean personas internas como sus trabajadores o externas como sus propios clientes.

Hoy en día no se debe centrar la atención en encontrar un método o una forma que sea la mejor para administrar, ahora la clave esta en ayudar a que los gerentes comprendan las diferencias situacionales y así poder responder a ellas de forma adecuada.

atención en encontrar un método o una forma que sea la mejor para administrar, ahora la clave esta en ayudar a que los gerentes comprendan las diferencias situacionales y así poder responder a ellas de forma adecuada.

Es importante resaltar que estamos en un mundo lleno de cambios que nos obliga ir a la par con el y por ende a las organizaciones, por lo tanto los temas administrativos de la actualidad se resumen en: 
"El compromiso para satisfacer las necesidades del cliente el 100 por ciento del tiempo, orienta a las organizaciones hacia la administración de la calidad total y el mejoramiento continuo de las operaciones. Actualmente, la economía globalizada es una influencia muy poderosa en las organizaciones, y abundan las oportunidades para aprender nuevas formas de administrar a partir de las prácticas de otros países. Esta es la era de la información en la cual el conocimiento y los trabajadores del conocimiento son recursos fundamentales de la sociedad moderna. Los nuevos gerentes deben aceptar y sobresalir en responsabilidades de liderazgo para desempeñarse como estrategas globales, maestros en tecnología, políticos consumados y lideres/motivadores. ${ }^{3}$

Finalmente solo resta señalar que trabajar en el ámbito de la administración es enriquecedor. En conclusión, como semillera de investigación se ha logrado identificar aspectos de la administración que enriquecen la formación y abarca diversos campos.

\title{
BIBLIOGRAFÍA
}

- CERTO, Samuel. Administración Moderna. Prentice Hall, 2001

- CHIAVENATO, Idalberto. Administración. Mc Graw Hill, 2001.

- RAMIREZ, Carlos. Fundamentos de Administración. Ecoe Ediciones, 1999

- STONER, James. Administration. Prentice Hall, 1996

-SCHERMERHORN, John. Administración. Limusa Wiley, 2003

\section{PROCESO DE MEJORAMIENTO DE LA}

\section{CALIDAD PRODUCTIVA DE PANELA EN}

\section{TRAPICHES UBICADOS EN EL MUNICIPIO DE LA PAZ, SANTANDER}

\author{
Alza W, Barrera Y \\ Reyes J, Villate $P_{\text {. }}$ \\ Grupo de Investigación en Química Ambiental (GIQUA).
}

\section{RESUMEN}

El Ministerio de la Protección Social expidió la Resolución 779 del 2006 por la cual se establece el reglamento técnico y los requisitos sanitarios que deben cumplir los establecimientos denominados trapiches paneleros para garantizar un producto inocuo. La Cooperativa de Productores y Comercializadores de La Paz 